\title{
The Effect of Company Characteristics on Disclosure Quality of Khartoum Stock Exchange Listed Companies
}

\author{
Alnour Nadir Alnour Osman ${ }^{1}$, Itra Nader Elnour Osman ${ }^{2}$ \\ ${ }^{1}$ School of Management Sciences, University of Khartoum, Khartoum, Sudan \\ ${ }^{2}$ Department of Business Administration, Sudan University College of Girls, Khartoum, Sudan
}

Email address:

mizyany@yahoo.com (A. N. A. Osman), itra.mhd@gmail.com (I. N. E. Osman)

\section{To cite this article:}

Alnour Nadir Alnour Osman, Itra Nader Elnour Osman. The Effect of Company Characteristics on Disclosure Quality of Khartoum Stock Exchange Listed Companies. International Journal of Economics, Finance and Management Sciences. Vol. 9, No. 2, 2021 , pp. $46-61$. doi: 10.11648/j.ijefm.20210902.11

Received: February 12, 2021; Accepted: February 23, 2021; Published: March 13, 2021

\begin{abstract}
This research aims to relate disclosure quality of published annual reports of listed companies in Khartoum Stock Exchange (KSE) to its hypothesized determinants. Such a relation, if exists, would be used to predict the level (size) and kind (quality) of accounting information disclosure. Annual reports of 42 listed companies in KSE out of 52 total listed companies for the year 2007 were used to assess the quality of disclosure. An unweighted disclosure index of 191 mandatory and voluntary information items was developed and utilized using all disclosure requirements by regulating bodies in Sudan, as well as relevant studies from nine developing countries. Actual degrees of disclosure quality of more than $80 \%$ of KSE listed companies were measured and analyzed. Correlation and Pearson Product Moment Correlation Coefficient Model tests were used to check the existence of association between the disclosure quality (the dependent variable) and seven independent variables (assets size, sales value, industry type, firm age, return on assets, liquidity ratio and debt ratio). Statistical analysis showed that disclosure quality was positively correlated to the firm size (measured in assets and sales values), and type of industry (measured in regulated versus non- regulated industry). On the other hand, the quality of disclosure was not significantly correlated to company age (measured in number of listing years), company profitability (measured in rate of return on assets) and company debt level (measured in liquidity and leverage ratios).
\end{abstract}

Keywords: Disclosure Quality, Disclosure Determinants, KSE, Firm Size, Industry Types and Company Performance

\section{Introduction}

Firm's characteristics such as size, type of industry, and performance create the firm image, which is highly affected by and may affect its surrounding environment. The hypothesized association between these characteristics and corporate disclosure, if proven, may explain the level of existing disclosure quality and predict the anticipated future degree of it.

Firm size is supposed to be positively correlated with disclosure quality. Large companies are better in disclosing their information, as they have no fear of losing competitive advantages by adequate disclosure. Additionally, large companies tend to have better access to modern technology and are more capable of producing information that is less costly. Many studies confirm positive correlation between firm size and disclosure quality, e.g., Abdullah, Ardiansah \&
Hamida found that firm size, company age and public ownership were significantly associated with disclosure levels in Indonesian companies [1].

Schadewitz \& Blevins found that disclosure quality in emerging markets is a regulatory driven, rather than a price driven, and hence, highlighted the effect of having a strong enforcement mechanism on improving disclosure quality, i.e. companies in regulated industry tend to provide better disclosure quality than companies in unregulated industry [2].

The impact of company age on disclosure quality can be explained in terms of learning curve. It, usually, takes the newly listed companies longer time to become familiar with the burden of being public companies, including their external financial accounting and reporting responsibilities. In other words, a company's disclosure score is supposed to increase over time as it becomes used to reporting 
regulations, which reflects the disciplinary roles of stock markets [3].

Based on the arguments of the Agency Theory, a positive effect of profitability on disclosure quality is expected because managers of profitable companies are more likely to disclose high quality information in their annual reports to justify their high salaries and incentives, on one hand, and to signal their superior performance to the market, on the other hand [4].

Liquidity and leverage are also assumed to be positively correlated with disclosure quality because companies tend to disclose more information about their performance to satisfy their lenders` needs for adequate and reliable information, and to comply with some covenant terms. Kamran \& Kourtis used meta- analysis to integrate 29 studies about corporate disclosure and its association with corporate specific characteristics. They confirmed significant and positive relationships between disclosure levels and corporate size, listing status and leverage [5].

\section{Brief Review of Literature}

Buzby tried to isolate the effects of size of assets, on disclosure quality, from those of listing status. Based on informational needs of financial analysts, a disclosure index was constructed with 39 voluntary information items in order to investigate the relationship between adequate disclosure and firm size and listing status.

The disclosure index was, then, applied to annual reports of a sample of 44 unlisted companies and 44 listed companies on either New York Stock Exchange or the other American stock exchanges. The two samples were matched with respect to size of assets, fiscal year ending dates and type of industry (manufacturing industry). Then, 44 matched pairs (a company from each sample in each pair) were constructed and tested statistically to ensure consistency between each pair and among the whole sample of the study.

The relative disclosure scores were statistically tested to check for an association between the extent of disclosure and the two company specific characteristics; listing status and size of assets. Statistical analyses indicated that the extent of disclosure had been positively associated with the size of assets, but not with the listing status [6].

Stagna tried to complement the study of Buzby by examining the influence of firm size and industry type on disclosure quality of large U.S.A. industrial firms. The author developed an index of 79 voluntary information items to measure disclosure quality of selected 80 large American industrial firms. Statistical analysis showed that type of industry, rather than firm size, was the major explanatory factor for the quality of disclosure [7].

Cooke examined annual reports of 90 manufacturing Swedish companies in order to assess the significance of relationship between disclosure levels as a dependent variable and listing status and firm size as independent variables. The study sample contained 38 unlisted companies, 33 companies listed on the Swedish Stock
Exchange (SSE) only, and 19 companies listed on the SSE with at least one foreign quotation (multiple listing). 224 information items were included in the study index, and disclosure scores were computed. It was found that firm size explained $56 \%$ of variations in disclosure extent while listing status explained the remaining 44\% [8].

Schadewitz \& Blevins examined the major determinants of interim disclosure in Finland. 29 independent variables were considered as determinants of disclosure levels in interim reports of Finnish listed companies. Using 256 interim reports of non-financial companies, the explanatory power of the research model was found to be $42 \%$. Out of the 29 independent variables, only ten variables were found to be significantly associated with discloser levels. These associated variables were institutional ownership, change in net sales and change in net investment (business risk), capital structure, growth, growth potential, size, and market maturity for the years 1990, 1991 and 1992. In term of significance of influential factors, Finnish interim disclosure over the period 1985-1993 was directly correlated to quantitative measures of business risk, capital structure, size and market maturing. It was, also, found that market risk and price adjustment variables had not been correlated to disclosure levels [2].

Mc Nally, Eng, \& and Hasseldine examined the quality of discretionary disclosure practices and their association with corporate characteristics in annual reports of 103 listed manufacturing companies in New Zealand, for the fiscal year 1979. Disclosure of 41 items was studied to examine the association between corporate disclosure and corporate characteristics, on one hand, and with unweighted index to measure the extent of corporate actual disclosure, on the other hand. Financial characteristics under study were firm size, rate of return, rate of growth, industry type and auditing firms. Of the three financial characteristics studied, only size of assets was found to be positively and significantly related to disclosure levels. Also, no relationship was found between disclosure levels and industry type or audit firms [9].

Chow investigated the extent of voluntary financial disclosure by 52 manufacturing listed companies in Mexico for the year 1982, and related it to the firm size, financial leverage and proportion of assets-in-place. Based on the study of Buzby, voluntary disclosure levels were measured with weighted and unweighted indexes of 24 items that considered optional. Multivariate regression models showed that there was a significant correlation between the extent of disclosure and both firm size and financial leverage. However, the disclosure extent was not significantly correlated with the assets-in-place [10].

Aljifri \& Hussainey explored, empirically, the factors that might affect the extent to which forward-looking information had been disclosed in annual reports of $74 \%$ of total listed companies in Dubai Financial Market and Abu Dhabi Securities Market in the U.A.E. Using a list of forwardlooking information, leverage was found to be significantly and positively correlated to levels of disclosing forwardlooking information. Inversely, sector type, audit firms and firm size variables were found to have an insignificant 
impact on the levels of disclosure [11].

Owusu-Ansah investigated the influence of eight corporate attributes on the extent of mandatory disclosure in annual reports of 49 listed non-financial companies in Zimbabwe for the year 1994. The adequacy of mandatory disclosure was measured by using an unweighted disclosure index of 32 disclosure items (disaggregated into 214 sub-items). Statistical analysis indicated that company size, ownership structure, company age, multinational corporate affiliation and profitability were significantly associated with the level of mandatory disclosure. On the other hand, the quality of external audit, industry type, and liquidity were statistically insignificant determinant of the level of mandatory disclosure [12].

Akhtaruddine investigated the extent of mandatory disclosure and its association with specific corporate characteristics (age, industry type, firm size, and profitability) in annual reports of 94 non-financial listed companies in Bangladesh for the year 1999. 160 information items were selected to measure the extent of disclosure using unweighted disclosure index. Only company size and profitability were found to be significantly associated with the extent of compliance with mandated requirements of disclosure [13].

\section{Methodology, Data Collection and Analysis}

To investigate disclosed and not disclosed information items, the researchers developed a wide-range disclosure index (list) that was not, specifically, directed at a particular group of users. Of course, bias could arise if the selected list was not sufficiently comprehensive.

The scope of the selection would usually be determined by the focus of the research, as there is no general theory on items' selection as stated by Wallace [14]. To overcome this deficiency, a list of information items studied by nine researchers was constructed to help determine items selection. These were the items studied by Mc Nally, Eng, \& and Hasseldine in New Zealand [9], Firer \& Meth in South Africa [15], Wallace in Nigeria [14], Naser \& and Nuseibeh in Saudi Arabia [16], Alrazeen in Saudi Arabia [17], Akhtaruddine in Bangladesh [13], Barako in Kenya [18], Aljifri \& and Hussainey in UAE [11], and Hossain in India [19]

The selection criterion was that any item investigated by two or more of these studies was included in the list. Additionally, any item required by a regulatory body in Sudan, and not mentioned in these previous studies was included, e.g., all Sudanese financial companies are subject to the standards of the Accounting and Auditing Organization of Islamic Institutions (AAOIFIs). Also, most items of the IASs check list of disclosure were included as many Sudanese companies, voluntarily, adopt the IFRS. Selection process results in a list of 191 items.

Opinion about information items that should be disclosed was extracted from annual reports of companies in the sample. At least, annual reports of two fiscal years of each company in the sample were used to check the applicability and non-applicability of each information item. Also, using available annual reports, a crosswise investigation was made for companies in each sector to get a double check for applicable information items.

Based on published annual reports of KSE listed companies, a disclosure sheet for each item, was prepared to display the number of companies to which each item was applicable and the number of companies which disclosed each applicable item. Then, disclosure statistics of information items were presented and analyzed. This was achieved by applying a dichotomy approach, i.e., an item scored " 1 " if it was disclosed, or " 0 " if it was applicable, but not disclosed. Therefore, each information item was evaluated by the ratio of the number of companies to which that item was applicable and the number of companies that disclosed the item as shown by the coming formula:

$$
\mathrm{TD}=\sum_{i=1}^{m} \mathrm{di}
$$

Where: $d_{i}=1$, if the item di is disclosed, or $d_{i}=0$, if the item di is applicable but not disclosed.

$\mathrm{m}<\mathrm{n}$ (number of applicable information items to be disclosed).

Once all items have been scored, an unweighted index is developed to measure the relative level of disclosure by a company. The index is the ratio of the total scores awarded to the company, to the maximum scores which that company is expected to earn. This relative index is calculated as:

$$
\mathrm{M}=\sum_{i=1}^{n} \mathrm{di}
$$

Where, $M$ denotes maximum score a company can earn, $d_{i}$ denotes the number of actual items disclosed, and $n$ is the number of items which the company is expected to disclose, i.e., $\mathrm{n} \leq 191$ items. Then, the total index (TI) for each company is the ratio: $\mathrm{TI}=\mathrm{TD} / \mathrm{M}$.

The year 2007 was chosen to ensure proper access to published annual reports of the studied companies. On $31 / 12 / 2007$, there were 52 listed companies in KSE. Out of them, the study sample contains 42 companies of about $97 \%$ of KSE capitalization ratio.

The study tries to test hypotheses that the quality of corporate disclosure in annual reports of Sudanese listed companies is positively and significantly associated with firm size, industry type, firm age, and firm performance (profitability, liquidity and leverage ratios). Such a relation is examined by correlation tests which state that two variables occur together in some specified manner, without implying that one causes the other [20].

Many techniques can be used to test correlation significance. However, this research uses Pearson Product Moment Correlation Coefficient Model. This model is used for continuously and linearly related variables. The correlation coefficient takes the form " $-1 \leq 0 \leq 1$ ". The value of the coefficient reveals the magnitude (the degree to which variables move in unison or opposition), whereas the coefficient sign signifies the direction of the relationship which tells whether large values on one variable are 
associated with large values on the other variable and small values with small values. When the variables correspond in this way, the two variables have a positive relationship. On the other hand, if the two variables are negatively related, large values on one variable are associated with small values on the other variable, and vice versa [21].

Levels of significance on which correlation coefficient is accepted will be 0.05 or 0.01 , since the studied observations are limited to only 42 cases (companies). Other levels of significance such as 0.10 or 0.25 are accepted for greater amounts of observations. If the correlation coefficient is equal to or more than 0.50 , then, there is a strong relationship between the dependent and independent variables. Also, positive and negative signs of correlation coefficient refer to the direction of the relationship between the dependent and independent variables. As the direction of the correlation may be a positive or a negative, a 2-tailed distribution is used [21].

To test its hypotheses, the study correlates the overall disclosure level (the dependent variable) with each of the corporate specific characteristics, which are assumed to be the determinants of disclosure quality (the independent variables). A hypothesis is accepted for a company characteristic if it is found that there is a significant statistical relationship between that characteristic and disclosure levels. Such relationships are measured statistically by coefficients of correlation between disclosure levels and each one of the specific characteristics.

\subsection{The Effect of Firm Size on Disclosure Quality}

In this research, firm size will be measured by assets size and values of annual sales. Assets value represents total resources available for a company (total capacity) whereas annual sales or revenues measure its activities for the whole period.

The research uses net values of fixed assets after deducting accumulated depreciation to refer to total assets' values. "Table 17 The effect of Assets Size on Disclosure Quality" in the appendices displays the effect of assets size on disclosure levels, where companies are ranked in a descending manner according to their asset's values. Disclosure mean of each company is, also, presented. To give more detailed picture, "Table 1 Disclosure Levels According to Assets Size" below was extracted from "Table 17 The effect of Assets Size on Disclosure Quality. The table shows that companies with large assets size have, on average, high disclosure levels. That is, 22 companies with assets size of more than 50,000,000 SDG have disclosure levels of more than 50\%. Among them, all companies whose assets are more than 500,000,000 SDG (12 companies) have disclosure levels of more than $50 \%$. On the other hand, 16 companies with assets size less than 50,000,000 SDG have disclosure levels of less than $50 \%$.

Table 1. Disclosure Levels According to Assets Size.

\begin{tabular}{|c|c|c|c|c|c|c|c|c|c|}
\hline \multirow{2}{*}{$\begin{array}{l}\text { Disc. Mean } \\
\text { in }(\%)\end{array}$} & \multicolumn{9}{|c|}{ Assets size of all companies in the study sample in (000) SDG } \\
\hline & $\begin{array}{l}\text { Up to } \\
25000 \\
\end{array}$ & $\begin{array}{l}25001- \\
50000 \\
\end{array}$ & $\begin{array}{l}50001- \\
100000 \\
\end{array}$ & $\begin{array}{l}100001- \\
200000\end{array}$ & $\begin{array}{l}200001- \\
500000\end{array}$ & $\begin{array}{l}500001- \\
1000000 \\
\end{array}$ & $\begin{array}{l}\text { Above } \\
1000000 \\
\end{array}$ & Total & $\%$ \\
\hline $20<30$ & 2 & & & & & & & 2 & 04.76 \\
\hline $30<40$ & 3 & 1 & & & 2 & & & 6 & 14.29 \\
\hline $40<50$ & 9 & 1 & 1 & 1 & & & & 12 & 28.57 \\
\hline $50<60$ & & & 1 & 1 & 7 & 5 & 4 & 18 & 42.86 \\
\hline $60<70$ & & & & 1 & & 1 & 1 & 3 & 07.14 \\
\hline$>70$ & & & & & & & 1 & 1 & 02.38 \\
\hline Total & 14 & 2 & 2 & 3 & 9 & 6 & 6 & 42 & 100.0 \\
\hline
\end{tabular}

Source: Table 17 The effect of Assets Size on Disclosure Quality.

Using Pearson correlation analysis, table 2 below shows that coefficient of correlation between assets size and disclosure level is found to be 0.697 and the correlation is significant at the 0.01 level. This coefficient means that assets value and disclosure degree are positively and significantly correlated. The correlation is strong (the correlation coefficient is more than 0.50 and the correlation is significant at the 0.01 level).

Table 2. Correlation between Assets Size and Disclosure Levels.

\begin{tabular}{llll}
\hline & & Disclosure Levels & Assets Category \\
\hline Disclosure levels & Pearson Correlation & 1.000 & .697 \\
& Sig. (2-tailed) &. & .000 \\
\multirow{2}{*}{ Assets size } & Number of Companies & 42 & 42 \\
& Pearson Correlation & .697 & 1.000 \\
& Sig. (2-tailed) & .000 &. \\
& Number of companies & 42 & 42 \\
\hline
\end{tabular}

Source: Researchers Own Calculations. Correlation is significant at the 0.01 level (2-tailed).

This result shows the positive effect of assets size on disclosure quality of annual reports of Sudanese listed companies. Hence, the study accepts that firm size (measured by assets size) is a determinant of disclosure quality in annual reports of Sudanese listed companies, which implies that assets size may be a predictor of disclosure quality of 
Sudanese listed companies.

The second measurement of firm size is annual sales values. "Table 18 The effect of Sales Values on Disclosure Quality" in the appendices shows that, on aggregate terms, companies with large annual sales values have, on average, high disclosure levels. "Table 3 Disclosure Levels According to Sales Values" is extracted from "Table 18 The effect of Sales Values on Disclosure Quality" to give more precise information on the effect of annual sales on disclosure levels. It shows disclosure levels of the study sample by sales categories.
The table shows that 15 companies of annual sales values of not more than 20,000 SDG have disclosure levels of less than $50 \%$. That is, except 4 companies, all companies whose annual sales values are less than 20,000 SDG (19 companies) have disclosure mean of less than $50 \%$. On the other hand, 19 companies of annual sales values of more than 20,000 SDG have disclosure levels of more than $50 \%$. That is, except 4 companies, all companies whose annual sales values are more than 20,000,000 (23 companies) have disclosure mean of more than $50 \%$.

Table 3. Disclosure Levels According to Sales Values.

\begin{tabular}{|c|c|c|c|c|c|c|c|c|c|}
\hline \multirow{2}{*}{$\begin{array}{l}\text { Disc. Mean in } \\
(\%)\end{array}$} & \multicolumn{9}{|c|}{ Annual sales values of all companies in the study sample in (000) SDG } \\
\hline & $\begin{array}{l}\text { Up to } \\
10000 \\
\end{array}$ & $\begin{array}{l}10001- \\
20000\end{array}$ & $\begin{array}{l}20001- \\
40000\end{array}$ & $\begin{array}{l}40001- \\
60000 \\
\end{array}$ & $\begin{array}{l}60001- \\
90000 \\
\end{array}$ & $\begin{array}{l}90001- \\
200000\end{array}$ & $\begin{array}{l}\text { Above } \\
200000\end{array}$ & Total & $\%$ \\
\hline $20<30$ & 2 & & & & & & & 2 & 04.76 \\
\hline $40<50$ & 6 & 3 & 1 & & 1 & & & 11 & 26.19 \\
\hline $50<60$ & 2 & 2 & 4 & 7 & 2 & 2 & & 19 & 45.24 \\
\hline $60<70$ & & & 1 & 1 & 1 & & & 3 & 07.14 \\
\hline Total & 13 & 6 & 7 & 8 & 4 & 3 & 1 & 42 & 100.0 \\
\hline
\end{tabular}

Source: Table 18 The effect of Assets Size on Disclosure Quality.

Table 3 highlighted the effect of annual sales volumes on disclosure levels in annual reports of Sudanese listed companies. However, the correlation between annual sales values and disclosure levels is not clear as the correlation between assets size and disclosure levels, although asset size and sales volumes are significantly correlated.

Using Pearson correlation analysis, the coefficient of correlation between firm size (measured in annual sales values) and disclosure level is found to be 0.531 and the correlation is significant at the 0.01 level, which means that firm size (measured in annual sales) and disclosure level are positively and significantly correlated, and the correlation is strong since the correlation coefficient is more than 0.50 . See "Table 4 Correlation between Annual Sales Value and Disclosure Levels" below:

Table 4. Correlation between Annual Sales Value and Disclosure Levels.

\begin{tabular}{llll}
\hline & & Annual Sales Values & Disclosure Levels \\
\hline Annual sales value & Pearson Correlation & 1.000 & .531 \\
& Sig. (2-tailed) &. & .000 \\
& Number of Companies & 42 & 42 \\
Disclosure levels & Pearson Correlation & .531 & .000 \\
& Sig. (2-tailed) & .000 &. \\
& Number of Companies & 42 & 42 \\
\hline
\end{tabular}

Source: Researchers Own Calculations. Correlation is significant at the 0.01 level (2-tailed).

Also, "Table 5 Correlation between Assets Size and Values of Annual Sales" below correlates the relationship between assets value and sales value. It shows that they are positively correlated, and the correlation is strong (more than 50\%).

Table 5. Correlation between Assets Size and Values of Annual Sales.

\begin{tabular}{llll}
\hline & & Value of Total Assets & Annual Sales \\
\hline Value of total assets & Pearson Correlation & 1.000 & .648 \\
& Sig. (2-tailed) & .000 & \\
& Number of companies & 42 & .648 \\
Annual sales & Pearson Correlation & .000 &. \\
& Sig. (2-tailed) & 42 & 42 \\
& Number of companies & 42 & .000 \\
\hline
\end{tabular}

Source: Researchers Own Calculations. Correlation is significant at the 0.01 level (2-tailed).

Hence, annual sales size is a determinant of disclosure quality and may be a predictor of disclosure quality of Sudanese listed companies. This result is consistent with the finding of Ikpor \& Nancy in Nigeria [22].

\subsection{The Effect of Industry Type on Disclosure Quality}

In Sudan, financial sector (namely banks and insurance companies) is regulated and operate under close supervision of the Central Bank through regulatory bodies. KSE lists both 
regulated and non-regulated companies. To test the effect of the industry type on disclosure levels, listed companies are classified as regulated or unregulated, on assumption that the disclosure quality is influenced by the regulations imposed on financial institutions by the Central Bank of Sudan. Regulated companies (financial institutions) are required to prepare their final accounts according to the standards of the AAOFIFs.
Unregulated companies (non-financial companies) have different references concerning their applied accounting standards. Table 19 The Effect of Industry Type on Disclosure Quality in the appendices shows the effect of this classification on disclosure degree. Table 6 is derived from "Table 19 The Effect of Industry Type on Disclosure Quality" to display categories of disclosure levels by industry type.

Table 6. Disclosure Levels According to Industry Type.

\begin{tabular}{|c|c|c|c|c|c|}
\hline \multirow{2}{*}{ Disc. Mean } & \multicolumn{2}{|c|}{ Regulated Companies } & \multicolumn{2}{|c|}{ Unregulated Companies } & \multirow{2}{*}{ Tota } \\
\hline & No. of Companies & $\%$ & No. of Companies & $\%$ & \\
\hline $20 \%<30 \%$ & & & 1 & 06.25 & 1 \\
\hline $30 \%<40 \%$ & 1 & 03.85 & 6 & 37.50 & 7 \\
\hline $40 \%<50 \%$ & 5 & 19.23 & 3 & 18.75 & 8 \\
\hline $50 \%<60 \%$ & 17 & 65.38 & 5 & 31.25 & 22 \\
\hline $60 \%<70 \%$ & 3 & 11.54 & & & 3 \\
\hline$>70 \%$ & 0 & & 1 & 06.25 & 1 \\
\hline Total & 26 & 100.0 & 16 & 100.0 & 42 \\
\hline
\end{tabular}

Source: Table 19 The Effect of Industry Type on Disclosure Quality.

"Table 6 Disclosure Levels According to Industry Type' shows that $77 \%$ of regulated companies have disclosure levels of more than $50 \%$, compared to $37 \%$ of unregulated companies.

Using Pearson correlation analysis, the coefficient of correlation between industry type and disclosure level is found to be 0.479 and the correlation is significant at the 0.01 level. "Table 7 Correlations between Industry Type and Disclosure Levels" below shows that industry type and disclosure level are positively and significantly correlated, but the correlation is not so strong since the correlation coefficient is less than 0.50 .

Table 7. Correlations between Industry Type and Disclosure Levels.

\begin{tabular}{llll}
\hline & & Industry Type & Disclosure Levels \\
\hline Industry type & Pearson Correlation & 1.000 & .479 \\
& Sig. (2-tailed) &. & .001 \\
Disclosure levels & Number of Companies & 42 & 42 \\
& Pearson Correlation & .479 & 1.000 \\
& Sig. (2-tailed) & .001 &. \\
& Number of Companies & 42 & 42 \\
\hline
\end{tabular}

Source: Researchers Own Calculations. Correlation is significant at the 0.01 level (2-tailed).

However, when Sudatel Company is excluded (an extreme value), Pearson correlation coefficient becomes 0.603 at significance levels of the 0.01 . Table 8 below indicates a strong positive correlation between industry type and disclosure levels of annual reports of Sudanese listed companies. Hence, the industry type is a determinant and may be a predictor of disclosure quality in annual reports of Sudanese listed companies. This result demonstrates a positive effect of regulations on improving disclosure levels.

Table 8. Correlation between Industry Type and Disclosure Levels after Excluding Sudatel.

\begin{tabular}{llll}
\hline & & Disclosure Levels & Industry Type \\
\hline Disclosure levels & Pearson Correlation & 1.000 & .603 \\
& Sig. (2-tailed) &. & .000 \\
Industry type & Number of Companies & 41 & \\
& Pearson Correlation & .603 & .00 \\
& Sig. (2-tailed) & .000 &. \\
& Number of Companies & 41 & 41 \\
\hline
\end{tabular}

Source: Researchers Own Calculations. Correlation is significant at the 0.01 level (2-tailed).

\subsection{The Effect of Company Age on Disclosure Quality}

Company age is measured by the number of listing years, because long period of listing makes a company more familiar with required regulations of KSE and be more compliant with disclosure requirements. KSE has started its operations since October 1994. Accordingly, listing years are calculated for every company as shown in "Table 20 The Effect of Company Age on Disclosure Quality" in the appendices. It displays the effect of company age on 
disclosure degree.

Table 9. Disclosure Levels According to Company Age.

\begin{tabular}{|c|c|c|c|c|c|c|c|}
\hline \multirow{2}{*}{ Disc. Mean } & \multicolumn{6}{|c|}{ Number of listing years } & \multirow{2}{*}{$\%$} \\
\hline & $0<3$ & $3<6$ & $6<9$ & $9<12$ & $>12$ & Total & \\
\hline $20 \%<30 \%$ & & 1 & & & & 1 & 02.38 \\
\hline $30 \%<40 \%$ & 1 & 2 & 2 & 2 & & 7 & 16.67 \\
\hline $40 \%<50 \%$ & 2 & & & 2 & 4 & 8 & 19.08 \\
\hline $50 \%<60 \%$ & 6 & 1 & 2 & 2 & 11 & 22 & 52.38 \\
\hline $60 \%<70 \%$ & & 1 & 1 & & 1 & 3 & 7.14 \\
\hline$>70 \%$ & & & & 1 & & 1 & 02.38 \\
\hline Total & 9 & 5 & 5 & 7 & 16 & 42 & 100.0 \\
\hline
\end{tabular}

Source: Table 20 The Effect of Company Age on Disclosure Quality.

Table 9 is derived from "Table 20 The Effect of Company Age on Disclosure Quality" to display disclosure levels in accordance with categories of listing years for all companies in the study sample. It shows that 12 companies with more than 12 years of listing have disclosure levels of more than $50 \%$. On the other hand, 8 companies with less than 6 years of listing have disclosure levels of more than $50 \%$. On contrary, the table also shows that 4 companies listed for more than 12 years have disclosure levels below $50 \%$, whereas 6 companies listed for less than 3 years have disclosure levels of more than $50 \%$.

Using Pearson correlation analysis, the coefficient of correlation between company age and disclosure levels is found to be 0.158 and the correlation is not significant at the 0.05 level (see Table 10 Correlation between Company Age and Disclosure Levels below).

Table 10. Correlation between Company Age and Disclosure Levels.

\begin{tabular}{llll}
\hline & & Disclosure Levels & Company Age \\
\hline Disclosure levels & Pearson Correlation & 1.000 & .158 \\
& Sig. (2-tailed) &. & .319 \\
Number of Companies & 42 & 42 \\
& Pearson Correlation & .158 & 1.000 \\
& Sig. (2-tailed) & .319 &. \\
& Number of Companies & 42 & 42 \\
\hline
\end{tabular}

Source: Researchers Own Calculations. Correlation is not significant at the 0.01 level (2-tailed).

Hence, the firm age is not a determinant of disclosure quality of Sudanese listed companies. This may be attributed to the fact that KSE has neither issued its own disclosure requirements, nor enforced applications of any set of accounting standards.

\subsection{The Effect of Profitability on Disclosure Quality}

The research measures company profitability by the rate of return on assets which relates net results of operations (net profits) to total resources used to accomplish those results.
Firm managers are likely to disclose more information when they possess good news reflected in good performance. "Table 21 The Effect of Profitability on Disclosure Quality" in the appendices displays the effect of profitability on disclosure degree and shows that KSE listed companies have poor profitability ratios (10\% are loss-makers, and only $12 \%$ have return on assets of more than $10 \%$.). Extracted from "Table 21 The Effect of Profitability on Disclosure", table 11 Disclosure Levels According to Profitability" displays disclosure levels at various categories of returns on assets.

Table 11. Disclosure Levels According to Profitability.

\begin{tabular}{|c|c|c|c|c|c|c|c|c|}
\hline \multirow{2}{*}{ Disc. Mean } & \multicolumn{7}{|c|}{ Return on Assets in Percentage } & \multirow{2}{*}{$\%$} \\
\hline & $0<2$ & $2<4$ & $4<6$ & $6<7$ & $7<10$ & $>10$ & Total & \\
\hline $20 \%<30 \%$ & 1 & & & & & & 1 & 02.38 \\
\hline $30 \%<40 \%$ & 3 & & & & & 2 & 5 & 11.90 \\
\hline $40 \%<50 \%$ & 2 & 2 & 3 & 1 & & 2 & 10 & 23.81 \\
\hline $50 \%<60 \%$ & 8 & 7 & 5 & 2 & & & 22 & 52.38 \\
\hline $60 \%<70 \%$ & 1 & 1 & & & & 1 & 3 & 07.14 \\
\hline$>70 \%$ & & & & & 1 & & 1 & 02.38 \\
\hline Total & 15 & 10 & 8 & 3 & 1 & 5 & 42 & 100.0 \\
\hline
\end{tabular}

Source: Table 21 The Effect of Profitability on Disclosure.

The table shows that 5 companies have rates of return on assets of more than $10 \%$. Out of them, 4 companies $(80 \%)$ have disclosure levels of less than $50 \%$. Inversely, 15 companies have rates of return on assets of less than $2 \%$. Out 
of them, 9 companies (60\%) have disclosure levels of more than $50 \%$.

Using Pearson correlation analysis, the coefficient of correlation between company performance (rates of return on assets) and disclosure level is found to be 0.131 and the correlation is not significant at the 0.05 (see table 12 Correlation between Profitability and Disclosure Levels). Therefore, profitability is not a determinant of disclosure quality of Sudanese listed companies.

Table 12. Correlation between Profitability and Disclosure Levels.

\begin{tabular}{llll}
\hline & & Return on Assets & Disclosure Levels \\
\hline Return on assets & Pearson Correlation & 1.000 & .131 \\
& Sig. (2-tailed) &. & .409 \\
Number of Companies & 42 & 42 \\
& Pearson Correlation & .131 & 1.000 \\
& Sig. (2-tailed) & .409 &. \\
& Number of Companies & 42 & 42 \\
\hline
\end{tabular}

Source: Researchers Own Calculations. Correlation is not significant at the 0.05 level (2-tailed).

The low levels of profitability of listed companies may, partially, explain this unexpected result. Also, Osman has stated that actual performance of KSE listed companies is not reflected on their share's prices [23]. In such cases, disclosing companies may not be rewarded for better disclosure due to the low rates of accounting information usage as stated by Hamza [24].

\subsection{The Effect of Liquidity on Disclosure Quality}

To reflect their ability to meet short term obligations when they fall due, liquid companies are supposed to provide better disclosure than do illiquid companies. The research measured liquidity by the current ratio, which relates current assets to current liabilities, on an assumption that current liabilities are used to finance current assets, and then current assets are used, later, to repay current liabilities at maturity dates. "Table 22 The Effect of Liquidity on Disclosure Quality" in the appendices displays the effect of liquidity on disclosure degree. Details of table 22 are displayed in table 13 below.

Table 13. Disclosure Levels According to Liquidity Position.

\begin{tabular}{|c|c|c|c|c|c|c|c|c|c|}
\hline \multirow{2}{*}{ Disc. Mean } & \multicolumn{8}{|c|}{ Current Ratios (Times) } & \multirow{2}{*}{$\%$} \\
\hline & $0<1$ & $1<1.5$ & $1.5<2$ & $2<3$ & $3<7$ & $7<10$ & $>10$ & Total & \\
\hline $20 \%<30 \%$ & & & 1 & & & & & 1 & 02.38 \\
\hline $30 \%<40 \%$ & & 2 & & & 1 & & & 3 & 07.14 \\
\hline $40 \%<50 \%$ & 3 & 7 & 1 & & & & 1 & 12 & 28.57 \\
\hline $50 \%<60 \%$ & 2 & 11 & 5 & 1 & 1 & 1 & 1 & 22 & 52.38 \\
\hline $60 \%<70 \%$ & & 2 & & 1 & & & & 3 & 07.14 \\
\hline$>70 \%$ & & & & 1 & & & & 1 & 02.38 \\
\hline Total & 5 & 22 & 7 & 3 & 2 & 1 & 2 & 42 & 100.0 \\
\hline
\end{tabular}

Source: Table 22 The Effect of Liquidity on Disclosure Quality.

The table shows that KSE companies have poor current ratios. 33 companies (above $80 \%$ of the sample) have current ratios of less than 2 times. Among them there are 22 Out of 26 financial institutions companies. Table 13 shows that disclosure levels of 26 companies are more than $50 \%$. Out of them, 20 companies $(77 \%)$ have current ratios of less than 2 times. Oppositely, 16 companies have disclosure levels of less than $50 \%$. Out of them, 14 companies (88\%) have current ratios of less than 2 times too.

Using Pearson correlation analysis, the coefficient of correlation between company liquidity and disclosure level is found to be 0.210 and the correlation is not significant at the 0.05 level (see Table 14 Correlation between Liquidity and Disclosure Levels). So, liquidity is not a determinant of disclosure quality of Sudanese listed companies.

Table 14. Correlation between Liquidity and Disclosure Levels.

\begin{tabular}{llll}
\hline & & Current Ratio & Disclosure Levels \\
\hline Current ratio & Pearson Correlation & 1.000 & .210 \\
& Sig. (2-tailed) &. & .182 \\
& Number of Companies & 42 & 42 \\
Disclosure levels & Pearson Correlation & .210 & 1.000 \\
& Sig. (2-tailed) & .182 &. \\
& Number of Companies & 42 & 42 \\
\hline
\end{tabular}

Source: Researchers Own Calculations. Correlation is not significant at the 0.05 level (2-tailed). 
The poor liquidity of Sudanese listed companies may, partially, explain this unexpected result. Also, Hamza has stated that many Sudanese banks do not base their short-term lending decisions on analyzing their clients' financial statements. Such lenders will not push for more disclosure if they are not interested in liquidity analysis [25].

\subsection{The Effect of Leverage on Disclosure Quality}

Leverage is an indicator of the capital structure. It measures how much creditors contribute to finance the firm assets as opposed to equity finance. Liquid and solvent companies are supposed to provide better disclosure to reflect their good credit worthiness, which will enable them to get more debt finance when needed, and in a relatively low cost.
In this research, a firm leverage level is measured by the debt ratio which relates total liabilities to total assets.

"Table 23 The Effect of Leverage on Disclosure Quality" in the appendices displays the effect of leverage on disclosure degree. Details of the effect of leverage on disclosure levels are presented in 'Table 15 Disclosure Levels According to Amounts of Debt" below, which is derived from 'Table 23 The Effect of Leverage on Disclosure Quality". It shows that 25 companies have debt ratios of more than $50 \%$. Out of them, 21 companies (84\%) are financial institutions. The table shows that 26 companies have disclosure levels of more than $50 \%$. Out of them, 13 companies have debt ratios of less than $60 \%$ and the other 13 companies have debt ratios of more than $60 \%$.

Table 15. Disclosure Levels According to Amounts of Debt.

\begin{tabular}{|c|c|c|c|c|c|c|c|c|}
\hline \multirow{2}{*}{ Disc. Mean } & \multicolumn{7}{|c|}{ Debt Ratios (\%) } & \multirow{2}{*}{$\%$} \\
\hline & $0<15$ & $15<30$ & $30<45$ & $45<60$ & $60<75$ & $>75$ & Total & \\
\hline $20 \%<30 \%$ & & 1 & & & & & 1 & 02.38 \\
\hline $30 \%<40 \%$ & 1 & 3 & 1 & 1 & 1 & 1 & 8 & 19.05 \\
\hline $40 \%<50 \%$ & 2 & & & 3 & & 2 & 7 & 16.67 \\
\hline $50 \%<60 \%$ & 2 & & 3 & 6 & 6 & 5 & 22 & 52.38 \\
\hline $60 \%<70 \%$ & & & 1 & & & 2 & 3 & 07.14 \\
\hline$>70 \%$ & & 1 & & & & & 1 & 02.38 \\
\hline
\end{tabular}

Source: Table 23 The Effect of Leverage on Disclosure Quality.

Using Pearson correlation analysis, the coefficient of correlation between company leverage ratio and disclosure level is found to be 0.254 and the correlation is not significant at the 0.05 level (see table 16). So, leverage is not a determinant of disclosure quality of Sudanese listed companies.

Table 16. Correlation between Leverage and Disclosure Levels.

\begin{tabular}{llll}
\hline & & Debt Ratio & Disclosure Levels \\
\hline Debt ratio & Pearson Correlation & 1.000 & .254 \\
& Sig. (2-tailed) &. & .104 \\
& Number of Companies & 42 & 42 \\
Disclosure Levels & Pearson Correlation & .254 & 1.000 \\
& Sig. (2-tailed) & .104 &. \\
& Number of Companies & 42 & 42 \\
\hline
\end{tabular}

Source: Researchers Own Calculations. Correlation is not significant at the 0.05 level (2-tailed).

Abdelmageed has stated that many bank loans are based on personal relationships with directors rather than on financial statements analyses [26].

\section{Conclusion}

The research has come up with the following findings concerning the effect of the firm characteristics on the degree of disclosure quality:

a) There is a positive and significant correlation between the degree of disclosure quality and firm size (measured in assets size and values of annual sales). The coefficient of correlation between levels of disclosure quality and assets size is 0.697 , and the coefficient of correlation between disclosure levels and values of annual sales is 0.531 . Both indicators are significant at the 0.01 level, which suggest that large companies are better in disclosing their information. Thus, firm size may be a predictor of the quality of accounting disclosure in published annual reports of Sudanese listed companies.

b) There is a positive and significant correlation between levels of disclosure quality and industry type (measured in regulated versus unregulated companies). The coefficient of correlation between levels of disclosure quality and industry type is 0.603 and the correlation is significant at the 0.01 level. This result may be attributed to the close supervision imposed on financial institutions by the Central Bank of Sudan. Thus, industry type can be considered as a predictor of accounting disclosure in annual reports of Sudanese listed companies.

c) Firm age (measured in the number of listing years) is not found to be significantly correlated with levels of 
disclosure quality. The coefficient of correlation between company age and levels of disclosure quality is 0.158 and the correlation is not significant at the 0.05 level. The insignificant correlation between company age and disclosure levels may indicate that KSE has not, yet, exercised its disciplinary role, although it has been established since 1994. The absence of the disciplinary role may be attributed to the fact that KSE has neither issued its own disclosure standards, nor recommended the adoption or application of already-set disclosure standards like the IFRSs.

d) Profitability (measured in rates of return on assets) is not found to be significantly correlated with the levels of disclosure quality. The coefficient of correlation between rates of return on assets and levels of disclosure quality is 0.131 and the correlation is not significant at the 0.05 level. This insignificant correlation may be attributed to the low rate of using accounting information by shareholders in Sudan (less than $10 \%$ ) as stated by Hamza [24]. e) Liquidity (measured in current ratio) is not found to be significantly correlated with levels of disclosure quality. The coefficient of correlation between liquidity ratios and disclosure quality is 0.210 and the correlation is not significant at the 0.05 level. This result is consistent with the finding of Hamza who has stated that only $21 \%$ of investment managers, in Sudanese banks, depend on accounting information in making their lending decisions [24].

f) Leverage (measured in debt ratio) is not found to be significantly correlated with levels of disclosure quality. The coefficient of correlation between liquidity and levels of disclosure quality is 0.254 and the correlation is not significant at the 0.05 level. Indicators of company performance have little or no effect on disclosure quality. This finding is consistent with those of Hamza who has found that about one third of the motives for shares' buying/ holding/ selling decision, in Sudan, is of non-economic nature [24].

\section{Appendix}

Table 17. The Effect of Assets Size on Disclosure Degree.

\begin{tabular}{|c|c|c|c|c|}
\hline \multirow{2}{*}{ Company Name } & \multirow{2}{*}{ Assets in (000) SDG } & \multirow{2}{*}{ Disc. Level } & \multicolumn{2}{|c|}{ Company Order } \\
\hline & & & Asset Size & Disc. \\
\hline Omdurman National Bank & 6289747 & 0.5789 & 1 & 8 \\
\hline Sudatel & 4672620 & 0.7349 & 2 & 1 \\
\hline Bank of Khartoum & 1709241 & 0.5641 & 3 & 10 \\
\hline Sudanese French Bank & 1087073 & 0.6076 & 4 & 4 \\
\hline Faisal Bank & 1030880 & 0.5921 & 5 & 6 \\
\hline Tadamon Islamic Bank & 1025474 & 0.5987 & 6 & 5 \\
\hline S F Z Company & 898194 & 0.5098 & 7 & 22 \\
\hline Alsalam Bank & 818709 & 0.5887 & 8 & 7 \\
\hline Islamic Devt. Cooperative Bank & 797396 & 0.6859 & 9 & 2 \\
\hline Farmer Commercial Bank & 649907 & 0.5638 & 10 & 11 \\
\hline Alshamal Islamic Bank & 544183 & 0.5503 & 11 & 15 \\
\hline Animal Resources Bank & 535071 & 0.5578 & 12 & 14 \\
\hline Emirates and Sudan Bank & 490630 & 0.5605 & 13 & 13 \\
\hline Sudanese Islamic Bank & 486430 & 0.5405 & 14 & 18 \\
\hline Saudi Sudanese Bank & 479777 & 0.5364 & 15 & 19 \\
\hline Export Development Bank & 389983 & 0.5163 & 16 & 21 \\
\hline United Capital Bank & 388640 & 0.5745 & 17 & 9 \\
\hline Blue Nile Bank & 356334 & 0.5333 & 18 & 20 \\
\hline Tala Investment Co. Ltd & 227730 & 0.3191 & 19 & 40 \\
\hline Workers` National Bank & 227219 & 0.5430 & 20 & 17 \\
\hline Nile Cement Company & 226730 & 0.3919 & 21 & 35 \\
\hline Financial Investment Bank & 194779 & 0.6259 & 22 & 3 \\
\hline Ivory Bank & 126809 & 0.4247 & 23 & 34 \\
\hline Islamic Development Company & 108940 & 0.5455 & 24 & 16 \\
\hline Global & 70718 & 0.5615 & 25 & 12 \\
\hline The National Reinsurance & 55230 & 0.4710 & 26 & 30 \\
\hline Joba Insurance & 27854 & 0.3617 & 27 & 38 \\
\hline The National Petroleum & 26519 & 0.4557 & 28 & 32 \\
\hline The Blue Nile Insurance & 20545 & 0.4965 & 29 & 27 \\
\hline Alrowad Financial Services Co. Ltd & 16549 & 0.3798 & 30 & 37 \\
\hline Assalama Insurance & 15473 & 0.5035 & 31 & 25 \\
\hline Almohager for Investment & 12210 & 0.5036 & 32 & 24 \\
\hline
\end{tabular}




\begin{tabular}{lllll}
\hline \multirow{2}{*}{ Company Name } & \multirow{2}{*}{ Assets in (000) SDG } & \multirow{2}{*}{ Disc. Level } & \multicolumn{2}{c}{ Company Order } \\
\cline { 4 - 5 } & & Asset Size & Disc. \\
\hline Almohager for Financial Services & 12000 & 0.5000 & 33 & 26 \\
Watania Co-operative Insurance & 7234 & 0.4745 & 34 & 29 \\
Modern Construction & 5784 & 0.4626 & 35 & 31 \\
Elnilein Insurance & 4158 & 0.4855 & 36 & 28 \\
Sudanese Kuwaiti Road Transport & 3163 & 0.2481 & 37 & 42 \\
Alriy Alaam Press and Publishing & 3162 & 0.3385 & 38 & 39 \\
General Insurance & 2195 & 0.5074 & 39 & 23 \\
Alhijra Exchange Co. Ltd & 2157 & 0.3814 & 40 & 36 \\
Alsaham for Financial Services & 1812 & 0.4274 & 41 & 33 \\
Tagseet & 1740 & 0.3022 & 42 & 41 \\
\hline
\end{tabular}

Source: Researchers Own Calculations.

Table 18. The Effect of Sales Values on Disclosure Degree.

\begin{tabular}{|c|c|c|c|c|}
\hline \multirow{2}{*}{ Company Name } & \multirow{2}{*}{ Sales in (000) SDG } & \multirow{2}{*}{ Disc. Level } & \multicolumn{2}{|c|}{ Company Order } \\
\hline & & & Sales & Disc. \\
\hline Sudatel & 1242206 & .7349 & 1 & 1 \\
\hline Alhijra Exchange Co. Ltd & 198971 & .3814 & 2 & 36 \\
\hline Omdurman National Bank & 166222 & 5789 & 3 & 8 \\
\hline Bank of Khartoum & 136438 & .5641 & 4 & 10 \\
\hline Tadamon Islamic Bank & 81389 & .5987 & 5 & 5 \\
\hline Faisal Bank & 78171 & .5921 & 6 & 6 \\
\hline Sudanese French Bank & 75590 & .6076 & 7 & 4 \\
\hline The National Petroleum & 69637 & .4557 & 8 & 32 \\
\hline Farmer Commercial Bank & 58754 & .5638 & 9 & 11 \\
\hline Emirates and Sudan Bank & 53911 & .5605 & 10 & 13 \\
\hline S F Z & 51144 & .5098 & 11 & 22 \\
\hline United Capital Bank & 51129 & .5745 & 12 & 9 \\
\hline Islamic Development Cooperative Bank & 50416 & .6859 & 13 & 2 \\
\hline Alsalam Bank & 46124 & .5887 & 14 & 7 \\
\hline Export Development Bank & 42119 & .5163 & 15 & 21 \\
\hline Sudanese Islamic Bank & 40271 & .5405 & 16 & 18 \\
\hline Nile Cement Company & 37109 & .3919 & 17 & 35 \\
\hline Saudi Sudanese Bank & 33929 & .5364 & 18 & 19 \\
\hline Financial Investment Bank & 32833 & .6259 & 19 & 3 \\
\hline Blue Nile Bank & 30738 & .5333 & 20 & 20 \\
\hline The National Reinsurance & 29656 & .4710 & 21 & 30 \\
\hline Alshamal Islamic Bank & 28761 & .5503 & 22 & 15 \\
\hline Animal Resources Bank & 28595 & .5578 & 23 & 14 \\
\hline Islamic Development Company & 23738 & .5455 & 24 & 16 \\
\hline Joba Insurance & 22627 & .3617 & 25 & 38 \\
\hline Assalama Insurance & 16225 & .5035 & 26 & 25 \\
\hline Workers` National Bank & 15253 & .5430 & 27 & 17 \\
\hline The Blue Nile Insurance & 15187 & .4965 & 28 & 27 \\
\hline Almohager for Financial Services & 11947 & .5000 & 29 & 26 \\
\hline Watania Co-operative Insurance & 9313 & .4745 & 30 & 29 \\
\hline Alriy Alaam Press and Publishing & 8672 & .3385 & 31 & 39 \\
\hline Alrowad Financial Services Co. Ltd & 8621 & .3798 & 32 & 37 \\
\hline Global & 6578 & .5615 & 33 & 12 \\
\hline Ivory Bank & 5302 & .4247 & 34 & 34 \\
\hline Elnilein Insurance & 4379 & .4855 & 35 & 28 \\
\hline Modern Construction & 3343 & .4626 & 36 & 31 \\
\hline Almohager for Investments & 3187 & .5036 & 37 & 24 \\
\hline General Insurance & 1810 & .5074 & 38 & 23 \\
\hline Tala Investment Co. Ltd & 684 & .3191 & 39 & 40 \\
\hline Tagseet & 500 & .3022 & 40 & 41 \\
\hline Alsaham for Financial Services & 411 & .4274 & 41 & 33 \\
\hline Sudanese Kuwaiti Road Transport & 410 & .2481 & 42 & 42 \\
\hline
\end{tabular}

Source: Researchers Own Calculations 
Table 19. The Effect of Industry Type on Disclosure Degree.

\begin{tabular}{|c|c|c|c|}
\hline \multirow{2}{*}{ Company Name } & \multirow{2}{*}{ Industry Type } & \multicolumn{2}{|c|}{ Company Order } \\
\hline & & Disc. & Order \\
\hline Sudatel & Unregulated & .7349 & 1 \\
\hline Islamic Development Co-operative Bank & Regulated & 6859 & 2 \\
\hline Financial Investment Bank & Regulated & .6259 & 3 \\
\hline Sudanese French Bank & Regulated & 6076 & 4 \\
\hline Tadamon Islamic Bank & Regulated & .5987 & 5 \\
\hline Faisal Bank & Regulated & .5921 & 6 \\
\hline Alsalam Bank & Regulated & .5887 & 7 \\
\hline Omdurman National Bank & Regulated & .5789 & 8 \\
\hline United Capital Bank & Regulated & .5745 & 9 \\
\hline Bank of Khartoum & Regulated & .5641 & 10 \\
\hline Farmer Commercial Bank & Regulated & .5638 & 11 \\
\hline Global & Unregulated & .5615 & 12 \\
\hline Emirates and Sudan Bank & Regulated & .5605 & 13 \\
\hline Animal Resources Bank & Regulated & .5578 & 14 \\
\hline Alshamal Islamic Bank & Regulated & .5503 & 15 \\
\hline Islamic Development Company & Unregulated & .5455 & 16 \\
\hline Workers` National Bank & Regulated & .5430 & 17 \\
\hline Sudanese Islamic Bank & Regulated & .5405 & 18 \\
\hline Saudi Sudanese Bank & Regulated & .5364 & 19 \\
\hline Blue Nile Bank & Regulated & .5333 & 20 \\
\hline Export Development Bank & Regulated & .5163 & 21 \\
\hline S F Z & Unregulated & .5098 & 22 \\
\hline General Insurance & Regulated & .5074 & 23 \\
\hline Almohager for Investments & Unregulated & .5036 & 24 \\
\hline Assalama Insurance & Regulated & .5035 & 25 \\
\hline Almohager for Financial Services & Unregulated & .5000 & 26 \\
\hline The Blue Nile Insurance & Regulated & .4965 & 27 \\
\hline Elnilein Insurance & Regulated & .4855 & 28 \\
\hline Watania Co-operative Insurance & Regulated & .4745 & 29 \\
\hline The National Reinsurance & Regulated & .4710 & 30 \\
\hline Modern Construction & Unregulated & .4626 & 31 \\
\hline The National Petroleum & Unregulated & 4557 & 32 \\
\hline Alsaham for Financial Services & Unregulated & .4274 & 33 \\
\hline Ivory Bank & Regulated & .4247 & 34 \\
\hline Nile Cement Company & Unregulated & .3919 & 35 \\
\hline Alhijra Exchange Co. Ltd & Unregulated & .3814 & 36 \\
\hline Alrowad Financial Services Co. Ltd & Unregulated & .3798 & 37 \\
\hline Joba Insurance & Regulated & .3617 & 38 \\
\hline Alriy Alaam Press and Publishing & Unregulated & .3385 & 39 \\
\hline Tala Investment Co. Ltd & Unregulated & .3191 & 40 \\
\hline Tagseet & Unregulated & .3022 & 41 \\
\hline Sudanese Kuwaiti Road Transport & Unregulated & .2481 & 42 \\
\hline
\end{tabular}

Source: Researchers Own Calculations

Table 20. The Effect of Company Age on Disclosure Degree.

\begin{tabular}{|c|c|c|c|c|}
\hline \multirow{2}{*}{ Company Name } & \multirow{2}{*}{ Listing Years } & \multirow{2}{*}{ Disc. Level } & \multicolumn{2}{|c|}{ Company Order } \\
\hline & & & Age & Disc. \\
\hline Sudanese French Bank & 13.00 & .6076 & 1 & 4 \\
\hline Tadamon Islamic Bank & 13.00 & .5987 & 1 & 5 \\
\hline Faisal Bank & 13.00 & .5921 & 1 & 6 \\
\hline Alshamal Islamic Bank & 13.00 & .5503 & 1 & 15 \\
\hline Islamic Development Company & 13.00 & .5455 & 1 & 16 \\
\hline Workers` National Bank & 13.00 & .5430 & 1 & 17 \\
\hline Sudanese Islamic Bank & 13.00 & .5405 & 1 & 18 \\
\hline Saudi Sudanese Bank & 13.00 & .5364 & 1 & 19 \\
\hline Export Development Bank & 13.00 & .5163 & 1 & 21 \\
\hline General Insurance & 13.00 & .5074 & 1 & 23 \\
\hline The Blue Nile Insurance & 13.00 & .4965 & 1 & 27 \\
\hline Elnilein Insurance & 13.00 & .4855 & 1 & 28 \\
\hline Watania Co-operative Insurance & 13.00 & .4745 & 1 & 29 \\
\hline The National Petroleum & 13.00 & .4557 & 1 & 32 \\
\hline Farmer Commercial Bank & 12.67 & .5638 & 15 & 11 \\
\hline Omdurman National Bank & 12.20 & .5789 & 16 & 8 \\
\hline
\end{tabular}




\begin{tabular}{|c|c|c|c|c|}
\hline \multirow{2}{*}{ Company Name } & \multirow{2}{*}{ Listing Years } & \multirow{2}{*}{ Disc. Level } & \multicolumn{2}{|c|}{ Company Order } \\
\hline & & & Age & Disc. \\
\hline The National Reinsurance & 11.90 & .4710 & 17 & 30 \\
\hline Nile Cement Company & 11.90 & .3919 & 17 & 35 \\
\hline Sudanese Kuwaiti Road Transport & 11.90 & .3022 & 17 & 42 \\
\hline Animal Resources Bank & 11.75 & .5578 & 20 & 14 \\
\hline Ivory Bank & 11.75 & .4247 & 20 & 34 \\
\hline Assalama Insurance & 11.33 & .5051 & 22 & 25 \\
\hline Sudatel & 10.75 & .7349 & 23 & 1 \\
\hline Financial Investment Bank & 8.67 & .6259 & 24 & 3 \\
\hline Joba Insurance & 7.90 & .3617 & 25 & 38 \\
\hline Almohager for Investments & 7.50 & .5036 & 26 & 24 \\
\hline Alriy Alaam Press and Publishing & 6.90 & .3385 & 27 & 39 \\
\hline Blue Nile Bank & 6.10 & .5333 & 28 & 20 \\
\hline Alrowad Financial Services Co. Ltd & 5.40 & .3798 & 29 & 37 \\
\hline Tagseet & 5.33 & .2481 & 30 & 41 \\
\hline S F Z & 5.25 & .5098 & 31 & 22 \\
\hline Alhijra Exchange Co. Ltd & 5.25 & .3814 & 31 & 36 \\
\hline Islamic Devt Cooperative Bank & 4.67 & .6859 & 33 & 2 \\
\hline Alsalam Bank & 2.50 & .5887 & 34 & 7 \\
\hline Emirates and Sudan Bank & 1.67 & .5605 & 35 & 13 \\
\hline Global & 1.50 & .5615 & 36 & 12 \\
\hline Alsaham for Financial Services & 1.33 & .4274 & 37 & 33 \\
\hline Bank of Khartoum & 1.00 & .5641 & 38 & 10 \\
\hline Modern Construction & 0.90 & .4626 & 39 & 31 \\
\hline United Capital Bank & 0.75 & .5745 & 40 & 9 \\
\hline Almohager for Financial Services & 0.75 & 5.000 & 41 & 26 \\
\hline Tala Investment Co. Ltd & 0.20 & .3191 & 42 & 40 \\
\hline
\end{tabular}

Source: Researchers Own Calculations

Table 21. The Effect of Profitability on Disclosure Degree.

\begin{tabular}{|c|c|c|c|c|}
\hline \multirow{2}{*}{ Company Name } & \multirow{2}{*}{ Return on Assets } & \multirow{2}{*}{ Disc. Level } & \multicolumn{2}{|c|}{ Company Order } \\
\hline & & & Profitability & Disc. \\
\hline Alhijra Exchange Co. Ltd & 25.60 & .3814 & 1 & 36 \\
\hline The National Reinsurance & 13.12 & .4710 & 2 & 30 \\
\hline Financial Investment Bank & 10.37 & .6259 & 3 & 3 \\
\hline Alsaham for Financial Services & 10.15 & .4274 & 4 & 33 \\
\hline Alrowad Financial Services Co. Ltd & 10.12 & .3798 & 5 & 37 \\
\hline Sudatel & 7.30 & 7349 & 6 & 1 \\
\hline Almohager for Financial Services & 6.98 & .5000 & 7 & 26 \\
\hline The National Petroleum & 6.90 & .4557 & 8 & 32 \\
\hline Global & 6.50 & .5615 & 9 & 12 \\
\hline The Blue Nile Insurance & 5.97 & .4965 & 10 & 27 \\
\hline Almohager for Investments & 5.90 & .5036 & 11 & 24 \\
\hline Modern Construction & 4.90 & .4626 & 12 & 31 \\
\hline Blue Nile Bank & 4.65 & .5333 & 13 & 20 \\
\hline Emirates and Sudan Bank & 4.62 & .5605 & 14 & 13 \\
\hline Elnilein Insurance & 4.60 & .4855 & 15 & 28 \\
\hline Islamic Development Company & 4.20 & .5455 & 16 & 16 \\
\hline Tadamon Islamic Bank & 4.13 & .5987 & 17 & 5 \\
\hline United Capital Bank & 3.57 & .5745 & 18 & 9 \\
\hline Nile Cement Company & 3.50 & .3919 & 19 & 35 \\
\hline Faisal Bank & 3.30 & .5921 & 20 & 6 \\
\hline Assalama Insurance & 3.30 & .5035 & 21 & 25 \\
\hline Alsalam Bank & 3.08 & .5887 & 22 & 7 \\
\hline Saudi Sudanese Bank & 3.03 & .5364 & 23 & 19 \\
\hline Export Development Bank & 2.50 & .5163 & 24 & 21 \\
\hline Sudanese French Bank & 2.20 & .6076 & 25 & 4 \\
\hline Farmer Commercial Bank & 2.16 & .5638 & 26 & 11 \\
\hline Joba Insurance & 2.16 & .3617 & 27 & 38 \\
\hline Sudanese Islamic Bank & 1.61 & .5405 & 28 & 18 \\
\hline Watania Co-operative Insurance & 1.60 & .4745 & 29 & 29 \\
\hline Workers` National Bank & 1.58 & .5430 & 30 & 17 \\
\hline Sudanese Kuwaiti Road Transport & 1.30 & .3022 & 31 & 42 \\
\hline Bank of Khartoum & 1.20 & .5641 & 32 & 10 \\
\hline
\end{tabular}




\begin{tabular}{lllll}
\hline \multirow{2}{*}{ Company Name } & \multirow{2}{*}{ Return on Assets } & \multirow{2}{*}{ Disc. Level } & \multicolumn{2}{l}{ Company Order } \\
\cline { 4 - 5 } & & Profitability & Disc. \\
\hline Omdurman National Bank & .86 & .5789 & 33 & 8 \\
Islamic Devt. Cooperative Bank & .82 & .6859 & 34 & 2 \\
Alshamal Islamic Bank & .42 & .5503 & 35 & 15 \\
S F Z & .40 & .5098 & 36 & 22 \\
Animal Resources Bank & .38 & .5578 & 37 & 14 \\
Tala Investment Co. Ltd & .00 & .3191 & 38 & 40 \\
Tagseet & -.11 & .2481 & 39 & 41 \\
Alriy Alaam Press and Publishing & -.20 & .3385 & 40 & 39 \\
General Insurance & -.40 & .5074 & 41 & 23 \\
Ivory Bank & -1.00 & .4247 & 42 & 34 \\
\hline
\end{tabular}

Source: Researchers Own Calculations.

Table 22. The Effect of Liquidity on Disclosure Degree.

\begin{tabular}{|c|c|c|c|c|}
\hline \multirow{2}{*}{ Company Name } & \multirow{2}{*}{ Current Ratio } & \multirow{2}{*}{ Disc. Level } & \multicolumn{2}{|c|}{ Company Order } \\
\hline & & & Liquidity & Disc. \\
\hline Global & 32.43 & .5615 & 1 & 12 \\
\hline Alsaham for Financial Services & 18.02 & .4274 & 2 & 33 \\
\hline Alsalam Bank & 8.87 & .5887 & 3 & 7 \\
\hline Alhijra Exchange Co. Ltd & 5.74 & .3814 & 4 & 36 \\
\hline United Capital Bank & 3.02 & .5745 & 5 & 9 \\
\hline Financial Investment Bank & 2.83 & .6259 & 6 & 3 \\
\hline Sudatel & 2.66 & .7349 & 7 & 1 \\
\hline Emirates and Sudan Bank & 2.61 & .5605 & 8 & 13 \\
\hline Omdurman National Bank & 1.98 & .5789 & 9 & 8 \\
\hline Tadamon Islamic Bank & 1.85 & .5987 & 10 & 5 \\
\hline Tagseet & 1.81 & .2481 & 11 & 41 \\
\hline Workers` National Bank & 1.75 & .5430 & 12 & 17 \\
\hline The National Reinsurance & 1.61 & .4710 & 13 & 30 \\
\hline Farmer Commercial Bank & 1.60 & .5638 & 14 & 11 \\
\hline Bank of Khartoum & 1.50 & .5641 & 15 & 10 \\
\hline Export Development Bank & 1.40 & .5163 & 16 & 21 \\
\hline Alrowad Financial Services Co. Ltd & 1.40 & .3798 & 17 & 37 \\
\hline Elnilein Insurance & 1.38 & .4855 & 18 & 28 \\
\hline Faisal Bank & 1.32 & .5921 & 19 & 6 \\
\hline Tala Investment Co. Ltd & 1.32 & .3191 & 20 & 40 \\
\hline Sudanese Islamic Bank & 1.30 & .5405 & 21 & 18 \\
\hline The National Petroleum & 1.29 & .4557 & 22 & 32 \\
\hline Saudi Sudanese Bank & 1.27 & .5364 & 23 & 19 \\
\hline Islamic Development Cooperative Bank & 1.26 & .6859 & 24 & 2 \\
\hline Alshamal Islamic Bank & 1.26 & .5503 & 25 & 15 \\
\hline Sudanese French Bank & 1.25 & .6076 & 26 & 4 \\
\hline Blue Nile Bank & 1.25 & .5333 & 27 & 20 \\
\hline Animal Resources Bank & 1.24 & .5578 & 28 & 14 \\
\hline Modern Construction & 1.18 & .4626 & 29 & 31 \\
\hline General Insurance & 1.17 & .5074 & 30 & 23 \\
\hline The Blue Nile Insurance & 1.17 & .4965 & 31 & 27 \\
\hline Ivory Bank & 1.16 & .4247 & 32 & 34 \\
\hline Assalama Insurance & 1.11 & .5035 & 33 & 25 \\
\hline Joba Insurance & 1.08 & .3617 & 34 & 38 \\
\hline Almohager for Investments & 1.07 & .5036 & 35 & 24 \\
\hline Watania Co-operative Insurance & 1.07 & .4745 & 36 & 29 \\
\hline S F Z & 1.05 & .5098 & 37 & 22 \\
\hline Islamic Development Company & 0.58 & .5455 & 38 & 16 \\
\hline Alriy Alaam Press and Publishing & 0.53 & .3385 & 39 & 39 \\
\hline Nile Cement Company & 0.36 & .3919 & 40 & 35 \\
\hline Almohager for Financial Services & 0.35 & .5000 & 41 & 26 \\
\hline Sudanese Kuwaiti Road Transport & 0.20 & .3022 & 42 & 42 \\
\hline
\end{tabular}

Source: Researchers Own Calculations 
Table 23. The Effect of Leverage on Disclosure Degree.

\begin{tabular}{|c|c|c|c|c|}
\hline \multirow{2}{*}{ Company Name } & \multirow{2}{*}{ Debt Ratio } & \multirow{2}{*}{ Disc. Mean } & \multicolumn{2}{|c|}{ Company Order } \\
\hline & & & Leverage & Disc. \\
\hline Bank of Khartoum & 87.52 & .5641 & 1 & 10 \\
\hline Ivory Bank & 83.67 & .4247 & 2 & 35 \\
\hline General Insurance & 83.52 & .5074 & 3 & 23 \\
\hline Joba Insurance & 82.50 & 3617 & 4 & 39 \\
\hline Watania Co-operative Insurance & 81.87 & .4745 & 5 & 29 \\
\hline Faisal Bank & 81.82 & .5921 & 6 & 6 \\
\hline Islamic Development Cooperative Bank & 80.11 & 6859 & 7 & 2 \\
\hline Alshamal Islamic Bank & 77.30 & .5503 & 8 & 15 \\
\hline Saudi Sudanese Bank & 77.13 & .5364 & 9 & 19 \\
\hline Sudanese French Bank & 76.93 & 6076 & 10 & 4 \\
\hline Assalama Insurance & 73.63 & .5035 & 11 & 25 \\
\hline Blue Nile Bank & 73.22 & .5333 & 12 & 20 \\
\hline Export Development Bank & 71.75 & .5163 & 13 & 21 \\
\hline Sudanese Islamic Bank & 70.65 & .5405 & 14 & 18 \\
\hline Alriy Alaam Press and Publishing & 70.64 & .3385 & 15 & 40 \\
\hline Animal Resources Bank & 69.82 & .5578 & 16 & 14 \\
\hline Almohager for Investments & 64.46 & .5036 & 17 & 24 \\
\hline The Blue Nile Insurance & 59.83 & .4965 & 18 & 27 \\
\hline Farmer Commercial Bank & 58.37 & .5638 & 19 & 11 \\
\hline The National Reinsurance & 57.45 & .4710 & 20 & 30 \\
\hline Almohager for Financial Services & 54.43 & .5000 & 21 & 26 \\
\hline Workers` National Bank & 54.03 & .5430 & 22 & 17 \\
\hline Alsalam Bank & 52.07 & .5887 & 23 & 7 \\
\hline Tagseet & 50.23 & .3022 & 24 & 42 \\
\hline Tadamon Islamic Bank & 50.16 & .5987 & 25 & 5 \\
\hline Omdurman National Bank & 49.39 & .5789 & 26 & 8 \\
\hline Elnilein Insurance & 47.71 & .4855 & 27 & 28 \\
\hline Emirates and Sudan Bank & 44.78 & .5605 & 28 & 13 \\
\hline Islamic Development Company & 41.79 & .5455 & 29 & 16 \\
\hline Modern Construction & 37.14 & .4626 & 30 & 31 \\
\hline Financial Investment Bank & 34.52 & .6259 & 31 & 3 \\
\hline United Capital Bank & 32.59 & .5745 & 32 & 9 \\
\hline Nile Cement Company & 29.80 & 3919 & 33 & 36 \\
\hline Sudatel & 25.47 & .7349 & 34 & 1 \\
\hline Alrowad Financial Services Co. Ltd & 21.37 & .3798 & 35 & 38 \\
\hline Sudanese Kuwaiti Road Transport & 20.59 & 2481 & 36 & 42 \\
\hline Alhijra Exchange Co. Ltd & 15.86 & .3814 & 37 & 37 \\
\hline The National Petroleum & 7.94 & .4557 & 38 & 33 \\
\hline Sudanese Free Zones (SFZ) & 7.10 & .5098 & 39 & 22 \\
\hline Alsaham for Financial Services & 5.41 & .4274 & 40 & 34 \\
\hline Global & 3.07 & .5615 & 41 & 12 \\
\hline Tala Investment Co. Ltd & .03 & .3191 & 42 & 41 \\
\hline
\end{tabular}

Source: Researchers Own Calculations

\section{References}

[1] M. F. Abdullah, M. N. Ardiansah \& N. Hamida (2017). The Effect of Company Size, Company Age, Public Ownership and Audit Quality on Internet Financial Reporting. Sriwijaya International Journal of Dynamic Economics and Business 1 (2): 153 .

[2] Schadewitz, H. J., \& Blevins, a. (1988). Major Determinants of Interim Disclosures in an Emerging Market. American Business Review Journal, Vol. 16.

[3] Elshabasy, Y. N. (2017). The impact of corporate characteristics on environmental information disclosure: an empirical study on the listed firms in Egypt. Yousra $N$. Elshabasy, Vol. 8 (Issue 5).

[4] Julius, O. (2016, June). The Effect of Profitability to the Disclosure of Corporate Social Responsibility on Mining Companies Listed on Indonesian Stock Exchange in the Year 2010-2012. Journal of Business and Management, Vol. 18 (Issue 6).

[5] Kamran Ahmed \& John Kourtis. (1999, March). Association between Corporate Characteristics and Disclosure Levels in Annual Reports: A Meta- Analysis. The British Accounting Reveiw, Vol. 31. 
[6] Buzby, S. L. (1975). Company Size, Listed Versus Unlisted Stocks, and the Extent of Financial Disclosure. Journal of Accounting Research, Vol. 13.

[7] Stagna, K. G. (1976). Disclosure in Published Annual Reports. Journal of Finance and Management, Vol. 7.

[8] Cooke, T. (1989). Disclosure in the Corporate Annual Reports of Swedish Companies. Accounting and Business Research, Vol. 19.

[9] Mc Nally, G. M., Eng, L. H., \& and Hasseldine, C. R. (1982). Corporate Financial Reporting in New Zealand: An Analysis of User Preference, Corporate Characteristics, and Disclosure Practices for Discretionary Information. Journal of Accounting and Business, Vol. 13.

[10] Chow, C. W.-B. (1987). Voluntary Financial Disclosure by Mexican Corporations. the Accounting Review Journal, Vol. 62.

[11] Aljifri, K., \& and Hussainey, K. (2008). The Determinants of Forward-Looking Information Disclosure in Annual Reports of UAE Companies. United Arab University.

[12] Owusu-Ansah, S. (1998). The Impact of Corporate Attributes on the Mandatory Disclosures in Zimbabwe. the International Journal of Accounting, Vol. 33.

[13] Akhtaruddine, M. (2005). Corporate Mandatory Disclosure Practices in Bangladesh. the International Journal of accounting, Vol. 40.

[14] Wallace, R. S. (1988). Corporate Financial Reporting in Nigeria. Journal of Accounting and Business Research, Vol. 18.

[15] Firer, C., \& Meth, G. (1986). Information Disclosure in Annual Reports in South Africa. International Journal of Management Sciences, Vol. 14.

[16] Naser, K., \& and Nuseibeh, R. (2003). Quality of Financial Reporting: Evidence from the Listed Saudi Non-Financial Companies. the International Journal of Accounting, Vol. 38.
[17] Alrazeen, A. (2004). The Interaction between Compulsory and Voluntary Disclosure in Saudi Arabia Corporate Annual Reports. Managerial Auditing Journal, Vol. 19.

[18] Barako, D. G. (2007). Determinants of Voluntary Disclosure in Kenyan Companies' Annual Reports. the African Journal of Business Management, Vol. 15.

[19] Hossain, M. (2008). The Extent of Disclosure in Annual Reports of Banking Companies: The Case of India. European Journal of Scientific Research, Vol. 23.

[20] Boris, B., Cooper, D. R., \& Schindler, a. P. (2005). Business Research Methods. the McGraw-Hill.

[21] Elhag, A. A. (2005). Statistical Analysis with SPSS. Cairo, Egypt: International Publishing and Printing Company.

[22] Ikpor Isaac Monday \& Agha Nancy (2016). Determinants of Voluntary Disclosure Quality in Emerging Economies: Evidence from Firms Listed in Nigeria Stock Exchange. International Journal of Research in Engineering \& Technology, Vol. 4, Issue 6.

[23] Osman, A. N. (1998). Evaluation of Capital Market Development in Sudan. Khartoum, Sudan: Unpublished M.Sc. Thesis, University of Khartoum.

[24] Hamza, M. O. (2002). A Perspective on the Utilization of Accounting Information in Developing Countries. Berlin, Germany: Verlag Dr. Crouster.

[25] Hamza, M. O. (1996). The External Usage Perspective of Accounting Information in Developing Countries. Khartoum, Sudan: Unpublished Ph.D. Thesis, University of Khartoum.

[26] Abdelmageed, S. M. (2007). Investments Decisions in Sudanese Commercial Banks. Khartoum, Sudan: Unpublished Graduation Project, University of Khartoum. 